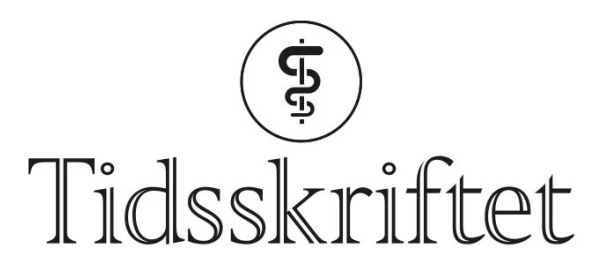

DEN NORSKE LEGEFORENING

\title{
Rastløse bein er et folkehelseproblem
}

\section{LEDER}

\section{EINAR KINGE}

ek@sandvikanevrosenter.no

Einar Kinge er spesialist i nevrologi ved Sandvika Nevrosenter - avtalespesialistene.

Forfatteren har fylt ut ICMJE-skjemaet og oppgir ingen interessekonflikter.

\section{Mange pasienter med søvnvansker, irritabel tarm og kroniske smerter er også plaget med rastløse bein.}

Rastløse bein (også kalt urolige bein, på engelsk restless legs) er en av de vanligst forekommende nevrologiske lidelsene i allmennpraksis (1). Tilstanden er forholdsvis enkel å diagnostisere, likevel er rastløse bein sannsynligvis både underdiagnostisert og underbehandlet.

Bjorvatn og medarbeidere publiserer nå en undersøkelse av hvor mange av pasientene ved et utvalg fastlegekontorer på Vestlandet og Sørlandet som fylte kriteriene for rastløse bein (2). Pasientene ble bedt om å fylle ut et spørreskjema om symptomer mens de ventet på legetime. Ikke overraskende fant forskerne en høy forekomst av rastløse bein $\mathrm{i}$ studiepopulasjonen. Samtidig som mange rapporterte hyppige og til dels alvorlige plager, var det få som benyttet medikamenter. Dette er i overensstemmelse med litteraturen (1 1 ) og egne erfaringer, og det sannsynliggjør at det er utilstrekkelig kunnskap om rastløse bein i allmennpraksis.

Rastløse bein kan gi et uttalt ubehag med betydning for livskvalitet og daglig funksjonsnivå. I tillegg til kribling i beina er det særlig nedsatt søvnkvalitet pasientene opplever som plagsomt. Majoriteten av pasienter med rastløse bein lider av søvnproblemer (3), og ofte er det årsaken til at pasienten oppsøker legen. De har gjerne nattlige periodiske beinbevegelser, som er assosiert med mikrooppvåkninger og dårlig nattesøvn. Dersom det er tvil om diagnosen og spesielt ved spørsmål om rastløse bein er årsaken til søvnproblemene, anbefales polysomnografi (4).

I Bjorvatn og medarbeideres studie fra allmennpraksis ble pasientene også spurt om symptomer på irritabel tarm, kronisk utmattelse og kroniske muskel- og ryggsmerter. Slike symptomer er vanlig blant pasienter som oppsøker fastlegen. Det viste seg at andelen som rapporterte om rastløse bein var betydelig høyere blant pasienter som også hadde disse diagnosene. Funnene er interessante, men ikke overraskende. Tidligere studier har vist høy komorbiditet mellom rastløse bein og blant annet kronisk smerte og irritabel tarm $(5, \underline{6})$. Min egen erfaring fra spesialistpraksis i nevrologi er at rastløse bein ofte er komorbid med muskel- og skjelettsmerter, og tilsvarende for migrene. Felles for samtlige tilstander er $\emptyset \mathrm{kt}$ 
forekomst av søvnvansker og psykiske lidelser. Ved migrene er det viktig å redusere triggerfaktorer, for eksempel søvnvansker, og flere pasienter har fortalt meg at behandlingen av rastløse bein har bedret migrenen.

\section{«Felles for samtlige tilstander er økt forekomst av søvnvansker og psykiske lidelser»}

Den høye forekomsten av rastløse bein som Bjorvatn og medarbeidere fant (15\%), kan muligens, som forfatterne også påpeker, være et resultat av seleksjonsskjevhet. I uselekterte materialer er prevalensen vist å ligge på 5-10\% (3). Det er kun de som har hyppige og alvorlige plager, som skal behandles. I henhold til nyere retningslinjer bør kalsiumkanalalfa-2-delta-antagonister (gabapentin og pregabalin) velges fremfor dopaminagonister (ropinirol, pramipeksol og rotigotin), fordi de sistnevnte kan forårsake en forverring av tilstanden (.7.). Lavest mulige effektive dose bør tilstrebes, og anbefalte maksimale doser bør overholdes. I behandlingsresistente tilfeller kan det være aktuelt med et opiat, enten alene eller som kombinasjonsterapi. Et kombinasjonspreparat med oksykodon + nalokson er

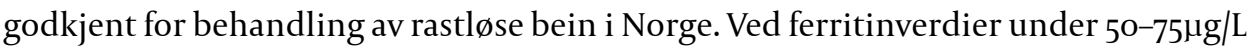
anbefales jerntilskudd (7.).

De fleste lever greit med rastløse bein, og det er kun et mindretall som skal behandles. Det er imidlertid viktig å påvise tilstanden og eventuelt behandle dem som er mye plaget. Min erfaring er at mange får forsinket diagnostisering og først får behandling etter lang tid med høyt lidelsestrykk. En nylig stor europeisk studie av de sosioøkonomiske konsekvensene av rastløse bein konkluderer med at bedret diagnostikk og behandling ikke bare kan minske lidelse, men også gi store samfunnsøkonomiske besparelser (1ํ). Bjorvatn og medarbeidere bidrar derfor med en viktig kartlegging av omfanget av et folkehelseproblem. Fastleger bør være oppmerksomme på tilstanden, særlig hos pasienter med søvnvansker og/eller andre vanlige tilstander som kronisk smerte, irritabel tarm og utmattelse. Vi trenger også flere studier som kan gi bedre forståelse av patofysiologien og i hvilken grad behandlingen av rastløse bein også kan bedre komorbide tilstander og vice versa.

\section{LITTERATUR}

1. Trenkwalder C, Tinelli M, Sakkas GK et al. Socioeconomic impact of restless legs syndrome management across European settings. Eur J Neurol 2021; 28: 691-706. [PubMed][CrossRef]

2. Bjorvatn B, Wensaas KA, Emberland KE et al. Rastløse bein - en studie fra almennpraksis. Tidsskr Nor Legeforen 2021; 141. doi: 10.4045/tidsskr.21.0333. [CrossRef]

3. Didato G, Di Giacomo R, Rosa GJ et al. Restless legs syndrome across the lifespan: symptoms, pathophysiology, management and daily life impact of the different patterns of disease presentation. Int J Environ Res Public Health 2020; 17:3658. [PubMed][CrossRef]

4. Kinge E, Ulfberg J. Søvnrelaterte bevegelsesforstyrrelser. Tidsskr Nor Lægeforen 2009; 129: 1888-91. [PubMed][CrossRef]

5. Hoogwout SJ, Paananen MV, Smith AJ et al. Musculoskeletal pain is associated with restless legs syndrome in young adults. BMC Musculoskelet Disord 2015; 16: 294. [PubMed][CrossRef]

6. Guo J, Pei L, Chen L et al. Bidirectional association between irritable bowel syndrome and restless legs syndrome: a systematic review and meta-analysis. Sleep Med 2021; 77: 104-11. [PubMed][CrossRef]

7. Garcia-Borreguero D, Silber MH, Winkelman JW et al. Guidelines for the first-line treatment of restless legs syndrome/Willis-Ekbom disease, prevention and treatment of dopaminergic augmentation: a combined task force of the IRLSSG, EURLSSG, and the RLS-foundation. Sleep Med 2016; 21: 1-11. [PubMed][CrossRef]

Publisert: 8. november 2021. Tidsskr Nor Legeforen. DOI: 10.4045/tidsskr.21.0733

(C) Tidsskrift for Den norske legeforening 2023. Lastet ned fra tidsskriftet.no 26. april 2023. 